\title{
PENGARUH LOGAM BERAT TIMBAL TERHADAP PERTUMBUHAN ALGA Halimeda opuntia YANG DIKULTUR DALAM WADAH TERKONTROL
}

\author{
(The Effect of Heavy metal lead (Pb) on the growth of Algae Halimeda opuntia Cultured in \\ Containers Controlled)
}

\author{
Kristi Aji Sugiarto ${ }^{1 *}$, Desy M.H. Mantirii ${ }^{1}$, Nickson J. Kawung ${ }^{1}$, Rizald M. Rompas ${ }^{1}$, \\ Sandra O. Tilaar ${ }^{1}$, Adnan Wantasen ${ }^{2}$
}

1. Program Studi IImu Kelautan, Fakultas Perikanan dan IImu Kelautan, Universitas Sam Ratulangi, Manado. 95115, Sulawesi Utara, Indonesia.

2. Program Studi Manajemen Sumberdaya Perairan, Fakultas Perikanan dan Ilmu Kelautan, Universitas Sam Ratulangi, Manado. 95115, Sulawesi Utara, Indonesia.

Corespodent author: dmh_mantiri@unsrat.ac.id

Heavy metal is a very dangerous pollutant waste for it cannot be destroyed (nondegradable) and over time it will accumulate in the ocean. This study aims to determine the lead content in sediment, water and algal thallus as well as to determine the algae growth that has been treated with lead. The research method used was a completely randomized design (CRD) which consisted of 3 treatments, using different treatments for each sample. The highest metal content obtained in the sediment was $5,124 \mathrm{ppm}$, in the water was $0.120 \mathrm{ppm}$, and in the algae thallus was 4,816 ppm respectively. The results showed that Halimeda opuntia algae can grow even in an environment contaminated with lead heavy metal and can become a bioremediation agent by absorbing lead heavy metal.

Keywords: Halimeda opuntia, Lead Heavy Metal, Algae Culture, Bioremediation

Logam berat merupakan salah satu limbah pencemar yang sangat berbahaya karena tidak dapat dihancurkan (non degradable) dan dapat terakumulasi di perairan laut. Penelitian ini bertujuan untuk mengetahui kandungan timbal pada sedimen, air dan thallus alga yang dikultur serta mengetahui pertumbuhan alga yang telah diberi perlakuan timbal. Metode penelitian mengunakan metode Rancangan Acak Lengkap (RAL) yang terdiri dari 3 perlakuan, dengan menggunakan perlakuan yang berbeda pada tiap sampel dan kontrol. Kandungan logam tertinggi yang didapatkan pada sedimen yaitu sebesar $5,124 \mathrm{ppm}$, pada air sebesar 0,120 ppm, dan pada thallus alga sebesar 4,816 ppm. Hasil yang diperoleh yaitu alga Halimeda opuntia dapat bertumbuh walaupun dalam lingkungan yang tercemar logam berat timbal serta mampu menjadi agen bioremediasi dengan menyerap logam berat timbal.

Kata kunci: Halimeda opuntia, Logam BeratTimbal, Kultur Alga, Bioremediasi 


\section{PENDAHULUAN}

Aktivitas antropogenik dan industri mempengaruhi keberadaan ekosistem di wilayah pesisir. Peningkatan kadar logam berat dalam air laut yang terjadi pada umumnya disebabkan oleh masuknya limbah rumah tangga, industri, pertambangan yang cukup banyak mengandung logam berat. Pencemaran logam berat merupakan suatu masalah yang sangat serius terhadap pengaruh kondisi lingkungan dan ekosistem perairan pada saat sekarang ini. Tidak adanya pengolahan terhadap limbah pembuangan, membuat perairan berpotensi terkontaminasi dengan bahan-bahan pencemar sehingga menimbulkan lingkungan tercemar (Lasut et al, 2008). Semakin banyak logam berat terakumulasi dalam perairan maka kehidupan organisme dalam perairan semakin terganggu termasuk ikan-ikan yang hidup di perairan tersebut dan pada akhirnya mengganggu kesehatan manusia (Goyer, 1981).

Penyebab utama yang menjadikan logam berat sebagai bahan pencemar berbahaya yaitu karena logam berat tidak dapat dihancurkan (non degradable) oleh organisme hidup di lingkungan dan akan terakumulasi ke lingkungan. Pencemaran yang terjadi mengandung bahan berbahaya, misalnya logam berat seperti timbal (Pb), mangan (Mn), tembaga $(\mathrm{Cu})$ dan cadmium $(\mathrm{Cd})$ cenderung meningkatkan kasus keracunan dan gangguan kesehatan masyarakat (Warni, 2017). Pada konsentrasi tertentu logam berat dapat berbahaya apabila masuk ke ekosistem laut. Efek toksik dari pencemaran tersebut dapat terjadi secara fisiologis, morfologi, genetik, hingga dapat menyebabkan kematian. Oleh karena itu diperlukannya suatu upaya pencegahan yang dikenal dengan bioremediasi. Makroalga bahkan mikroalga merupakan biota laut yang mampu mengabsorpsi logam berat seperti terlihat pada sel alga (Kemer et al 2020; Mantiri et al 2019).

Makroalga merupakan tumbuhan berklorofil, tubuhnya merupakan thallus (uniseluler dan multi seluler) yang hidup di air, alat reproduksi pada umumnya berupa sel tunggal, meskipun ada juga yang reproduksinya tersusun dari banyak sel (Dawes, 1981; Siahaan et al, 2015). Makroalga tumbuh di perairan dangkal (intertidal dan sublitoral) dimana cahaya matahari masih dapat terpenetrasi pada habitatnya, kemampuan makroalga untuk berfotosintesis menyebabkan makroalga termasuk produsen primer pada ekosistem perairan, khususnya di laut. Pada umumnya makroalga ditemukan melekat pada bebatuan, terumbu karang serta pada cangkang moluska.

Makroalga kaya akan nutrisi dan senyawa metabolit sekunder antara lain pigmenpigmen klorofil, fikobilin dan karotenoid (Dawes, 1981; Mantiri, 2000). Makroalga juga memiliki pigmen tambahan berupa fikosianin (berwarna biru), fikosantin (berwarna pirang) dan fikoeritrin (berwarna merah) (Mantiri et al, 2003). Makroalga terbagi menjadi 3 divisi, yaitu alga hijau (Chlorophyta), alga merah (Rhodophyta) dan alga coklat (Phaeophyta) (Trono,1997).

Alga hijau (Chlorophyta) merupakan kelompok alga yang paling maju dan banyak sifat-sifat tanaman tingkat tinggi. Kelompok ini adalah organisme prokariotik dan memiliki struktur sel khusus. Selain pigmen yang berperan dalam proses fotosistesi alga hijau terdeteksi memiliki senyawa bioaktif seperti anti kanker, anti oksidan, antitumor (Kemer et al 2019; Mantiri et al 2019).

Oleh karena fungsi lain dimana alga hijau mengandung senyawa bioaktif dan salah 
satu spesiesnya Halimeda opuntia ditemukan sepanjang tahun di perairan Teluk Totok, maka penelitian ini dilakukan di laboratorium dengan perlakuan pemberian timbal. Tujuannya untuk melihat pertumbuhan alga dan mengetahui kandungan timbal pada sedimen, air dan thallus alga.

\section{Metode Penelitian}

Pengambilan sampel alga dilakukan di perairan Likupang, depan Marine Field Station, pengambilan air laut untuk kultur dilakukan di perairan Bahowo Tongkaina, proses kultur alga dilakukan di Laboratoriuan Akuakultur Fakultas Perikanan dan IImu Kelautan dan analisis logam pada sampel dilakukan di Balai Riset dan Standarisasi Indutri (BARISTAND) Manado

Pengambilan sampel alga Halimeda opuntia dilakukan di tempat dimana daerah tersebut jauh dari pencemaran dan atau daerah yang relatif bersih seperti perairan laut depan Marine Field Station yang berada di Likupang. Sampel alga diidentifikasi merujuk pada buku Trono (1997). Alga yang diperlukan diambil secukupnya agar tidak merusak ekosistem di perairan tersebut. Sampel alga yang diperoleh dimasukan ke dalam kotak pendingin untuk menyimpan alga selama perjalanan menuju ke Laboratorium Akuakultur Fakultas Perikanan dan IImu Kelautan Unsrat.

Selain sampel alga, sampel sedimen dan air laut diambil di perairan laut Bahowo Tongkaina dengan alasan daerah tersebut masih memiliki kualitas air dan sedimen yang relatif bersih dan jaraknya cukup jauh dari pemukiman penduduk. Sampel air yang diambil dimasukan ke dalam 4 buah galon ukuran 25 liter, begitu juga dengan sedimen yang diambil dimasukan kedalam 1 karung berukuran 25 kilogram.

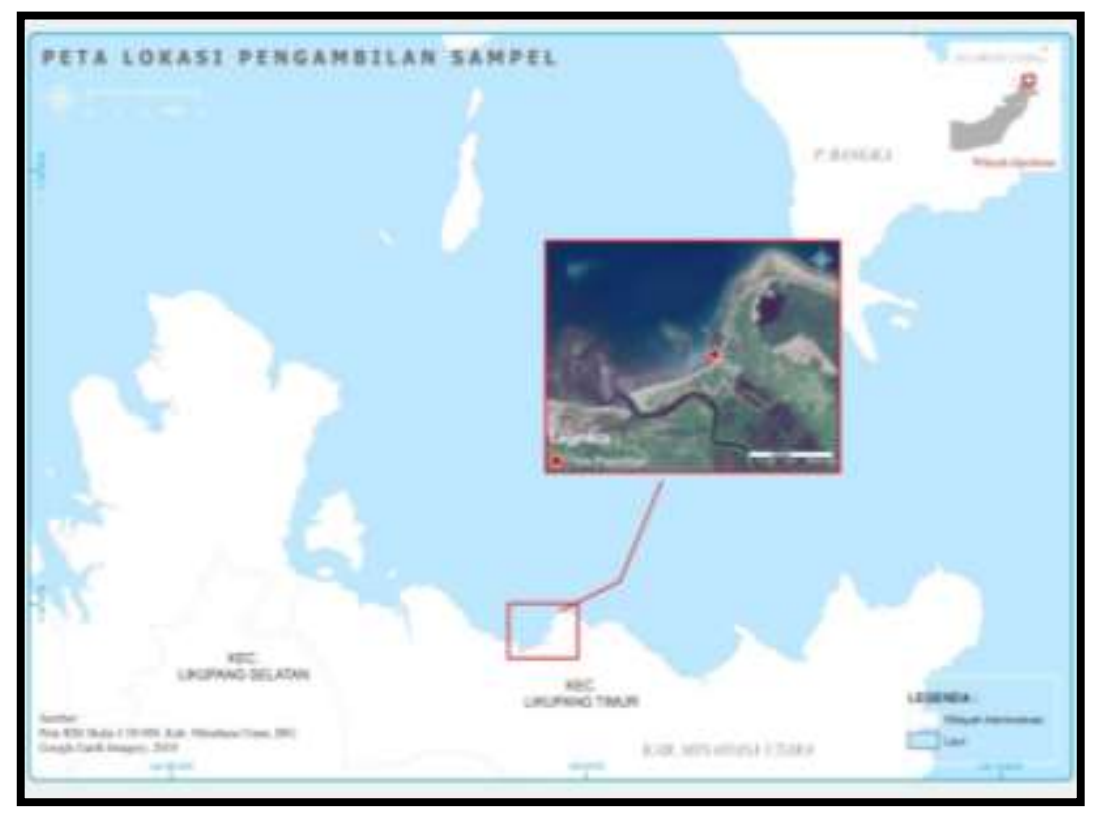

Gambar 1. Peta Lokasi Pengambilan Sampel di Marine Field Station Likupang, Kecamatan Likupang, Minahasa Utara 
Setelah dilakukan pengambilan sampel, kemudian sampel alga dan sedimen tersebut dibersihkan dari organisme yang berasosiasi maupun yang terbawa oleh arus dan gelombang. Air laut yang sudah diambil harus disterilkan terlebih dahulu menggunakan mesin autoclave agar air yang digunakan untuk kultur bisa terbebas dari bakteri kontaminan.

Sebelum masuk dalam proses kultur, berbagai alat dan bahan seperti wadah, aerator dan lainnya harus depersiapkan telebih dahulu. Wadah kultur ditempatkan di dekat jendela dengan tujuan agar alga yang akan dikultur bisa mendapatkan penetrasi cahaya untuk berfotosintesis. Setelah itu dimasukan sedimen yang sudah dibersihkan ke dalam wadah dan diatur hingga merata kemudian dimasukan air yang sudah distrerilkan dengan ukuran 4 liter air laut steril dan 1 liter aquades, penambahan aquades diperlukan dikarenakan air laut yang disterilkan memiliki kadar salinitas yang tinggi. Alga yang sudah dibersihkan dimasukan ke dalam wadah dan diatur bisa menancap pada sedimen yang ada.

Sebelum masuk pada proses kultur, dilakukan suatu proses aklimatisasi selama 1 minggu untuk melihat apakah alga tersebut bisa untuk dikultur. Setelah proses aklimatisasi berhasil, alga kan dikultur selama 7 minggu lamanya.

Makroalga memiliki peranan secara ekologis bagi ekosistem laut sebagai produsen primer dalam rantai makanan (Prathep et al., 2011). Meskipun demikian, alga juga memerlukan nutrisi agar bisa bertumbuh. Nutrien terbagi atas dua yaitu, nutrien alami dan nutrien buatan, nutrien alami merupakan zat atau senyawa yang berasal dari alam itu sendiri seperti contohnya nitrogen dan fosfor. Sedangkan nutrien buatan merupakan hasil dari percampuran zat atau senyawa yang dibuat sedemikian rupa seperti contoh yaitu conway.

Pemberian nutrien conway pada alga dilakukan setiap 1 minggu sekali, takaran yang diberikan sebanyak 1 tetes pada masing-masing wadah. Setelah pemberian nutrien dilakukan, alga yang dikultur perlu juga diberikan polysorbate dengan tujuan agar bisa memudahkan logam yang akan diberikan terpenetrasi dengan baik ke dalam alga.

Penelitian ini dilaksanan secara eksperimental menggunakan rancangan acak lengkap (RAL) yang terdiri dari 3 perlakuan, dengan menggunakan perlakuan yang berbeda pada tiap sampel yang ada (10 ppm; 25 ppm; 50 ppm).

Untuk menentukan berapa banyaknya timbal asetat yang akan digunakan dalam penelitian maka digunakan rumusan sebagai berikut:

$$
\mathrm{M} 1=\frac{\mathrm{V} 1 \times \mathrm{V} 2}{\mathrm{M} 2}
$$

Hasil perhitungan dari setiap perlakuan yang berdasarkan rumus di atas adalah sebagai berikut:

Kontrol $\quad: \mathrm{Pb}(0 \mathrm{ppm} / 0 \mathrm{mg})$

Perlakuan 1: $\mathrm{Pb}(10 \mathrm{ppm} / 1,48 \mathrm{mg})$

Perlakuan $2: \mathrm{Pb}(25 \mathrm{ppm} / 37,20 \mathrm{mg})$

Perlakuan 3 : Pb (50 ppm/ 74,4 mg)

Timbal tersebut ditimbang menggunakan timbangan analitik, setelah didapatkan hasil perhitungan kemudian dimasukan ke dalam masing-masing wadah.

Analisis kualitas air dilakukan secara exsitu dengan melihat parameter berupa suhu dan salinitas. Untuk analisis parameter logam pada air, sedimen dan thallus alga dilakukan di Laboratorium Balai Riset dan Standarisasi Indrustri Manado. 


\section{Hasil dan Pembahasan}

\section{Pengamatan Kultur Alga}

Dalam hasil pengamatan, alga yang dikultur selama tujuh minggu di laboratorium akuakultur, menunjukan terjadinya pertumbuhan secara morfologi. Pemberian nutrien buatan berupa conway diketahui dapat membantu alga untuk bertumbuh. Hal tersebut menandakan bahwa alga yang dikultur secara ex-situ masih dapat bertumbuh walaupun telah diberikan perlakuan logam berat.

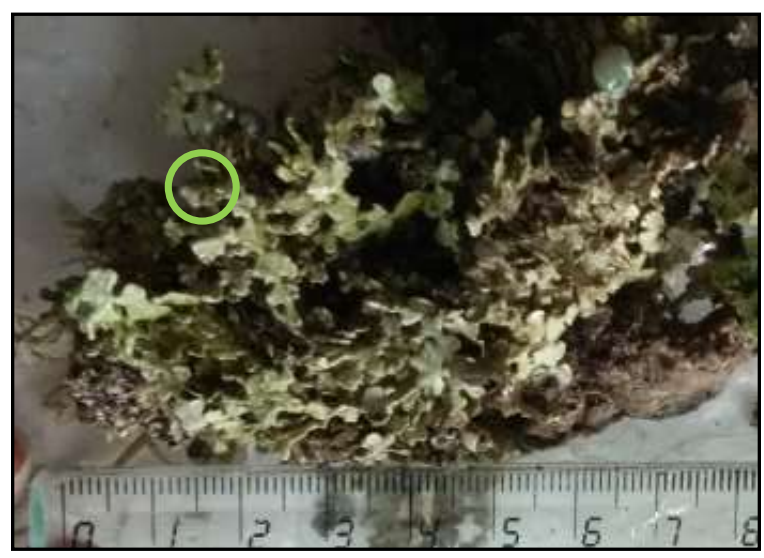

Gambar 2. Pertumbuhan Alga H. Opuntia

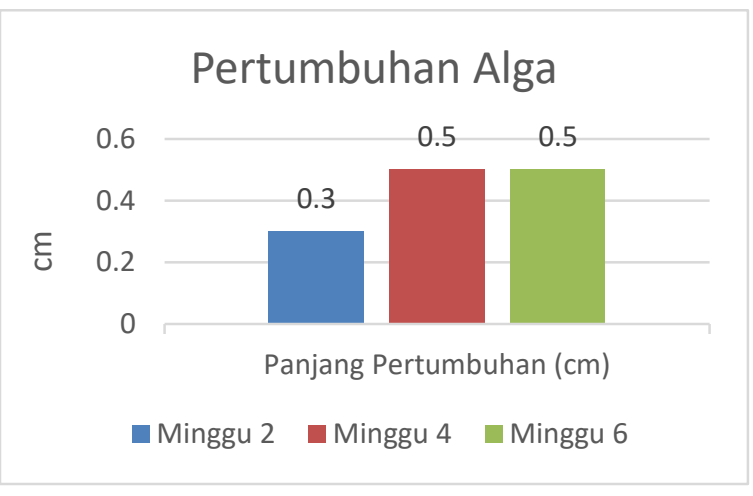

Gambar 3. Grafik Pertumbuhan Alga H. Opuntia

Pertumbuhan $H$. opuntia terlihat dari tunas yang tumbuh (gambar 2), ukuran tunas yang tumbuh diukur setiap dua minggu sekali dimana hasil pertumbuhan yang teramati adalah sekitar $0,3 \mathrm{~cm}$ pada minggu kedua, bertumbuh sedikit pada minggu keempat sekitar $0,5 \mathrm{~cm}$, dan pada minggu keenam tidak terjadi perubahan dan tetap memiliki ukuran $0,5 \mathrm{~cm}$.

\section{Analisis Kulitas Air}

Pengukuran parameter kualitas air secara ex-situ yaitu suhu dan salinitas. Suhu di laboratorium Akuakultur berkisar $28^{\circ} \mathrm{C}-$ $32^{\circ} \mathrm{C}$. Salinitas yang didapatkan yaitu $35 \mathrm{ppt}$.

\section{Analisis Timbal Pada Air}

Berdasarkan Keputusan Menteri Negara Lingkungan Hidup No. 51 Tahun 2004 mengenai Baku Mutu Air Laut untuk Biota Laut dimana kandungan logam berat yang boleh masuk ke perairan laut mempunyai batasan tertentu. Adapun pengukuran kualitas air yaitu suhu $30^{\circ} \mathrm{C}$ dan salinitas $35 \%$

Kandungan timbal asetat yang dimasukan ke dalam wadah air yang berbeda dan dengan berbagai perlakuan dalam jangka waktu tujuh minggu kultur menunjukan hasil yang beragam dimana hasil yang didapatkan adalah seperti berikut:

Pada Gambar 4, hasil yang diperoleh perlakuan kesatu (P1) minggu kedua dan keempat (M2 dan M4) tidak terjadi perubahan, kandungan logam terbanyak terdapati pada minggu keenam (M6).

Pada perlakuan kedua (P2) minggu kedua (M2) tidak ada perubahan, terjadi penurunan konsentrasi pada minggu keempat (M4), kenaikan terjadi pada minggu keenam (M6) walaupun tidak lebih tinggi dari perlakuan kesatu (P1).

Perlakuan ketiga (P3) di minggu kedua (M2) tidak terjadi perubahan, terjadi kenaikan konsentrasi pada minggu keempat (M4), penurunan terjadi pada minggu keenam (M6). 


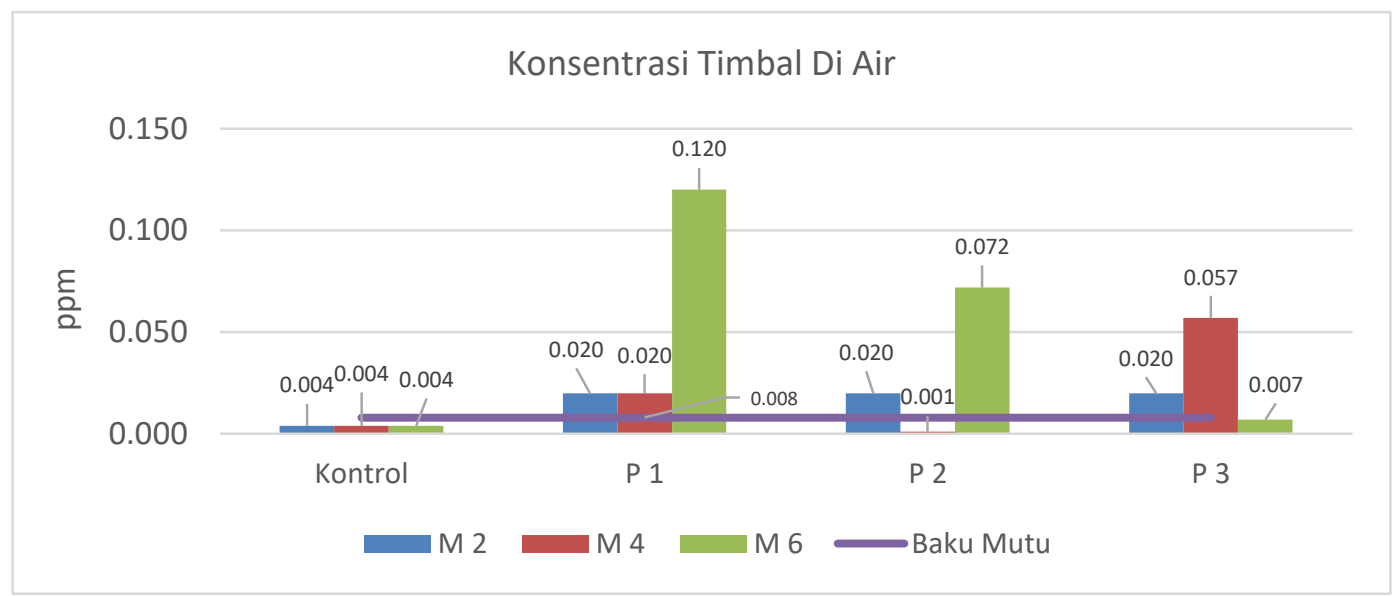

Keterangan:

Gambar 4. Grafik Konsentrasi Timbal Pada Air

$\mathrm{M} 2$ = Minggu kedua, $\mathrm{M} 4$ = Minggu keempat, $\mathrm{M} 6=$ Minggu keenam

Kontrol, P1 = Perlakuan kesatu, P2 = Perlakuan kedua, P3 = Perlakuan ketiga

Di perairan rendahnya kadar logam karena dipengaruhi oleh arus dan gelombang (Hosea, 2019). Terjadinya penurunan konsentrasi timbal dalam air di wadah kultur diasumsikan terjadi karena adanya penambahan air ke dalam wadah untuk menjaga volume air agar sama.

\section{Analisis Timbal Pada Sedimen}

Terbentuknya senyawa kimia dalam sedimen disebabkan oleh karena berbagai reaksi yang akan mempengaruhi habitat serta kehidupan organisme, proses-proses fisik kimia lainnya yang terjadi dalam sedimen, seperti: adsorpsi-desorpsi, solidifikasi-disolusi akan mempengaruhi komposisi kimia sedimen dan lapisan air di permukaan sedimen (sediment-water interface) melalui interaksi air-sedimen (Sanusi, 2006). Kandungan logam berat di sedimen tergantung pada komposisi kimia dan mineral sedimen (Sanusi, 2006).

Kandungan timbal asetat yang dimasukan ke dalam wadah dan mengendap di sedimen dalam jangka waktu tujuh minggu lamanya kultur menunjukan hasil yang beragam dimana hasil yang didapatkan adalah seperti berikut:

Pada Gambar 5 hasil yang diperoleh pada perlakuan kesatu (P1) dimana kandungan timbal minggu kedua (M2) lebih tinggi dari kontrol, dan pada minggu keempat (M4) kandungan timbal naik, namun, terjadi penurunan pada minggu keenam (M6).

Pada perlakuan kedua (P2) di minggu kedua (M2) konsentrasi timbal didapatkan cukup tinggi dan meningkat pada minggu keempat (M4) namun terjadi penurunan pada minggu keenam (M6).

Pada perlakuan ketiga (P3) di minggu kedua (M2) kandungan timbal cukup tinggi dan terjadi kenaikan pada minggu keempat (M4) melebihi standar baku, namun pada minggu keenam (M6) terjadi penurunan.

Hutagalung, (1999) menyatakan bahwa logam berat mempunyai sifat yang mudah mengikat bahan organik dan mengendap di dasar perairan dan bersatu dengan sedimen sehingga kadar logam berat dalam sedimen lebih tinggi dibanding dalam air. 


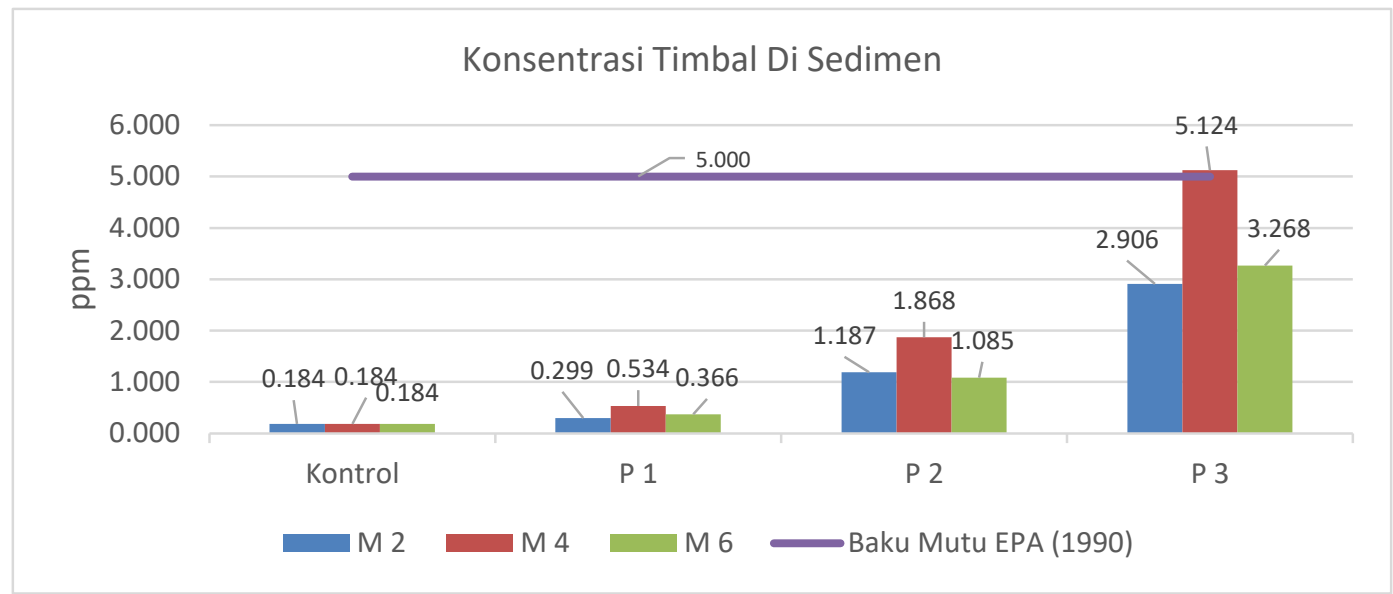

Gambar 6. Konsentrasi Timbal pada Sedimen

Keterangan:

M2 = Minggu kedua, M4 = Minggu keempat, M6 = Minggu keenam

Kontrol, P1 = Perlakuan kesatu, P2 = Perlakuan kedua, P3 = Perlakuan ketiga

\section{Analisis Timbal Pada Thallus H.opuntia}

Alga yang dikultur di laboratorium akuakultur pada tahap awal dilakukan aklimatisasi selama 1 minggu. Kemudian dilakukan pemberian perlakuan yang berbeda terhadap tiap sampel alga yang dikultur yaitu, sempel kesatu sebanyak 0 ppm (0 mg), sampel kedua sebanyak 10 ppm (1,4 mg), sampel ketiga sebanyak 25 ppm $(37,20 \mathrm{mg})$, sampel keempat sebanyak 50 ppm $(74,4 \mathrm{mg})$ dari total timbal asetat yang tersedia sebanyak $3360 \mathrm{mg}$.

Analisis logam berat pada alga dilakukan di Laboratorium Balai Riset dan Standarisasi lindustri (BARISTAND) Manado. analisis logam pada thallus menggunakan Spektrofotometri Serapan Atom (AAS).

Sampel alga yang dikultur di laboratorium memiliki konsentrasi timbal dengan berat awal sebesar 0,09 ppm dan hasil ukuran tersebut menjadi kontrol.

Hasil pengukuran timbal (Gambar 7) pada alga di minggu kedua (M2) perlakuan kesatu (P1) didapatkan sebesar 0,207 ppm, perlakuan kedua (P2) didapatkan sebesar
0,583 ppm, perlakuan ketiga (P3) sebesar 1,261 ppm.

\section{MINGGU 2}

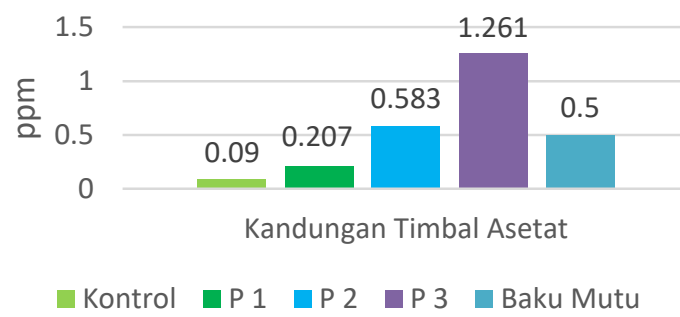

Gambar 7. Konsentrasi Timbal Minggu 2

Pada minggu kedua (M2) diperlakuan kesatu (P1), perlakuan kedua (P2) dan perlakuan ketiga (P3) yang diberikan, didapati bahwa alga mampu mengabsorbsi timbal dengan baik.

Pada Gambar 8, hasil yang diperoleh pada minggu keempat (M4) yaitu kontrol sebesar 0,09 ppm, perlakuan kesatu (P1) sebesar 0,874 ppm, perlakuan kedua (P2) sebesar 0,104 ppm, dan pada perlakuan ketiga (P3) sebesar 4,367 ppm. 


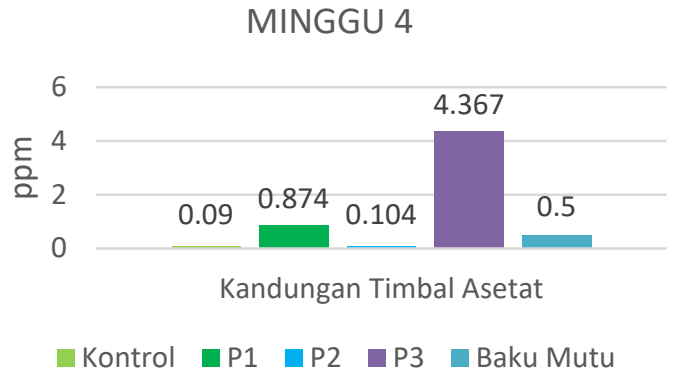

Grafik 8. Konsentrasi Timbal Minggu 4

Pada minggu keempat (M4) diperlakuan kesatu (P1) dan perlakuan ketiga (P3) yang diberikan, alga mampu mengabsorbsi timbal dengan baik berbeda dengan perlakuan kedua (P2) hanya terjadi penyerapan yang relatif sangat sedikit.

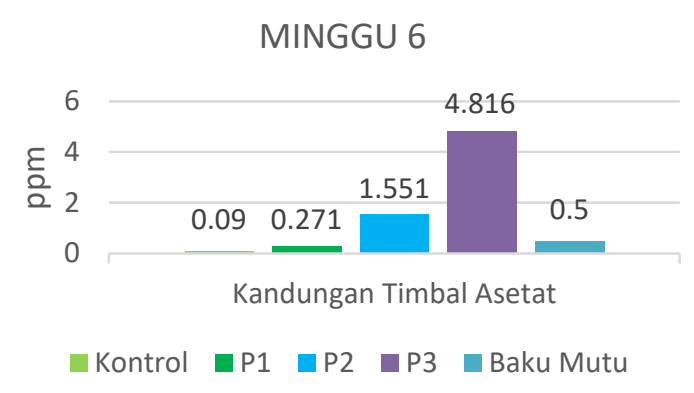

Gambar 9. Konsentrasi Timbal Minggu 6

Hasil analisis yang diperoleh seperti pada gambar 9, pada minggu keenam (M6) kontrol 0,09 pm, kemudian pada perlakuan kesatu (P1) didapatkan hasil sebesar 0,271 ppm, perlakuan kedua (P2) sebesar 1,551 ppm, dan pada perlakuan 3 sebesar 4,816 ppm.

Pada minggu keenam (M6) diperlakuan kedua (P2) dan perlakuan ketiga (P3) yang diberikan, alga mampu mengabsorbsi timbal dengan baik berbeda dengan perlakuan kesatu (P1) hanya terjadi penyerapan yang relatif sangat sedikit.

Berdasarkan hasil pengukuran di atas, kandungan logam yang terdeteksi pada sedimen dapat tertransfer pada thallus alga selama proses kultur, apalagi dalam wadah, dengan sirkulasi tertutup. Di alam, hasil penelitian alga yang tumbuh secara alami dari Kepel et al., 2018 di Teluk Totok menunjukan bahwa kandungan logam arsen yang terdapat pada sedimen dimana alga Ulva sp. tumbuh mempunyai konsentrasi 24 ppm, terdeteksi juga pada thallus alga Ulva sp. dengan konsentrasi 4,8 ppm. Demikian juga hasil penelitian dari Mantiri et al., 2019 menunjukan bahwa konsentrasi logam terdeteksi pada sedimen yaitu logam arsen mempunyai kisaran 1-3 ppm dan merkuri 0.05-3.2 ppm. Konsentrasi logam arsen pada thallus dari Padina australis yang hidup di Teluk Totok mempunyai kisaran 1.1-19.5 ppm dan untuk logam merkuri mempunyai kisaran 0.003-0.758 ppm. Hasil penelitian dari Hosea et al., 2019 pada alga Kappaphycus alvarezii yang dibudidayakan di perairan Teluk Totok dengan metode lepas dasar menunjukan bahwa alga dapat tumbuh walaupun kandungan logam timbal pada thallus alga di minggu ke-3 terdeteksi cukup tinggi (1,49 ppm).

Berdasarkan analisis penelitian dari Mantiri et al., 2019 menunjukan bahwa alga Halimeda opuntia yang berasal dari teluk Totok yang telah tercemar logam berat memiliki aktifitas antioksidan sebesar 16387771,05 $\mathrm{\mu g} / \mathrm{mL}$. Penelitian tentang kandungan logam yang terdeteksi pada sedimen dan thallus alga, baik yang tumbuh alami di perairan, dibudidaya di perairan terbuka atau dikultur dalam wadah terkontrol, tidak dapat mempengaruhi pertumbuhan alga. Dengan demikian alga mampu menyerap logam dan dapat menjadi agen bioremediasi.

\section{Kesimpulan}

Kandungan timbal tertinggi pada air didapati pada minggu keenam (M6) perlakuan kesatu (P1) dengan total 0,120 ppm dan melewati strandar baku mutu. 
Kandungan timbal pada sedimen yang telah melewati batas baku mutu hanya terjadi pada minggu keenam (M6) diperlakuan kedua (P2) dengan total 5,124 ppm. Kandungan timbal pada alga kebanyakan melewati batas baku mutu dimana didapati bahwa konsentrasi terendah didapati pada Pada perlakuan kedua (P2) minggu kedua (M2) sebesar 0,583 ppm, konsentrasi yang tertinggi didapati pada Pada perlakuan ketiga (P3) minggu keenam (M6) sebesar 4,816 ppm.

Alga yang dikultur dalam wadah yang terkontrol dapat bertumbuh walaupun sudah diberikan perlakuan logam berat, pertumbuhan alga dapat dilihat dari tunas yang bermunculan.

\section{Daftar Pustaka}

Dawes, C.J. 1981. Marine Botany. John Wiley and Sons, Inc. New York.

Goyer, R.A. 1981. Disorder of Mineral Metabolism. Academic Press. 159$199 \mathrm{pp}$

Hosea, F., D.M.H. Mantiri, dan J.J.H. Paulus. 2019. Analisis Logam Timbal (Pb) Pada Kappaphycus alvarezii (Doty) Alga Merah Yang Di Budidaya Di Teluk Totok Minahasa Tenggara, Sulawesi Utara. Jurnal Pesisir dan Laut Tropis. 7(3):158-166.

Hutagalung, H.P., D. Setiapermana, dan S. H. Riyono. 1999. Metode Analisa Air Laut, Sedimen dan Biota. Jakarta P30-LIPI.

Kemer K. Mantiri D.M.H., Angkouw E. D., Kondoy K.I.F., Kase A. 2019. Antitumor Activities on Halimeda opuntia, Halymenia durvillaei, Padina australis, and Laurencia pappilosa Marine Algae from Nain Island Waters. J. of Ecology Environment \& Conservation. Vol 25, Aug Suppl. Issue, 2019; Page: S7-S11.
Kemer K., Rompas R.M., Rimper J.R., Margyaningsih N.I. 2020. Transmission electron microscope analysis upon growth of lead acetate treated microalga, Dunaliella sp. AACL Bioflux, Volume 13, Issue 2: 849-856

Kepel, R.C., Mantiri, D.M.H., Paransa, D.S.J., Paulus, J.J.H., Nasprianto., and Wagey, B.T., 2018. Arsenic content, cell structure, and pigment of Ulva sp. from Totok Bay and Blongko waters, North Sulawesi, Indonesia. AACL Bioflux, 2018, Volume 11, Issue 3.

Lasut, M.T., Jensen, K.R, and Shivakoti G. 2008. Analysis of Constraints and Potentials for Wastewater Management in The Coastal City of Manado, North Sulawesi, Indonesia. Journal of Environmental Management. 88:1141-1150.

Mantiri D.M.H. 2000. Pigmen Dari Organisme Laut Sebagai Pewarna Alami Jurnal Fakultas Perikanan Vol 1(4), Hal: 91-93

Mantiri D.M.H., R Ch. Kepel, J. Manan. 2003. Isolasi jenis-jenis pigmen karotenoid dari alga hijau Caulerpa racemosa (Forsskal) J. Agardh. Jurnal Perikanan dan IImu Kelautan Vol 1 (5) Hal: 16-27.

Mantiri D.M.H., R Ch. Kepel., B. T Wagey, and Nasprianto. 2018. Heavy Metal Content, Cell Structure, and Pigment of Halimeda opuntia (Linnaeus) JV Lamouroux from Totok Bay and Blongko Waters, North Sulawesi, Indonesia. J. of Ecology Environment \& Conservation. Vol 24 (3): 54-62 pp.

Mantiri D.M.H., R Ch. Kepel., A. Rumengan, and A. O Kase. 2019. Analysis of Antioxidant and Chlorophyll in Green Algae from Totok Bay and Tongkaina Waters, North Sulawesi. Journal of Ecology Environment \& Conservation. Vol 25, Aug Suppl. Issue, 2019; Page: S135-S140 
Nasprianto, Mantiri, D.M.H, Gerung G.S. 2019. Metal Concentration in Water, Sediment, and Green Alga Halimeda Opuntia (Linnaeus) J.V. Lamouroux From Totok Bay and Blongko Waters, North Sulawesi. J. Ilmiah Platax Vol. 7:(1), Jan. 2019

Prathep A., S. Pongparadon A. Darakrai B. Wichachucherd and S. Sinutok. 2011. Diversity and distribution of seaweed at Khanom. Mu Ko Thale Tai National Park, Nakhon Si Thammarat Province, Thailand. Songklanakarin J. Sci. Technol. 33 (6): 633-640.

Sanusi, H.S. 2006. Kimia Laut, Proses Fisik Kimia dan Interaksinya dengan Lingkungan. Bogor: Departemen Ilmu dan Teknologi Kelautan, Fakultas Perikanan dan IImu Kelautan. Institut Pertanian Bogor. 188h.
Siahaan, D.O., D.M.H. Mantiri, dan A. Rumengan. 2015. Kajian Awal Fitoremediasi Merkuri pada Caulerpa serrulata dan Halimeda macroloba dari Perairan Teluk Totok. Jurnal Pesisir dan Laut Tropis. 2(1):31-37pp.

Trono, G.C. 1997. Field Guide and Atlas of the Seaweed Resources of the Philippines. Bookmarks, Inc. Makaty City. 306 hal.

Warni, D. 2017. Analisis Logam Pb, Mn, Cd Pada Sedimen Di Pelabuhan Jetty Meulaboh, Aceh Barat. Jurnal IImiah Mahasiswa Kelautan dan Perikanan Unsyaih 2(2):246-253. 